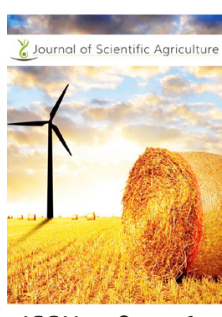

ISSN: $2184^{-0261}$
Received: June 01, 2021

Revised: September 09, 2021

Accepted: September 12, 2021

Published: October 13, 2021

*Corresponding author:

Mohammad Safar Noori,

E-mail: safar_noori@yahoo.com

\section{Growth and yield of onion (Allium cepa L.) as influenced by application of organic and inorganic fertilizers}

\author{
Abdul Bari Andishmand', Mohammad Safar Noori* \\ 'Department of Horticulture Faculty of Agriculture, Takhar University, Afghanistan, '2Department of Agronomy, \\ Faculty of Agriculture, Takhar University, Afghanistan
}

\begin{abstract}
This study was carried out to ascertain the effects of organic manure (farm yard manure, poultry manure and vermicompost) and chemical fertilizers NPK (nitrogen, phosphorus and potassium) on growth and yield of onion. The research was consisting ten treatments with three replications. Different levels of nitrogen $\left(0,100\right.$ and $\left.150 \mathrm{~kg} \mathrm{ha}^{-1}\right)$, phosphorus $\left(0,75\right.$ and $\left.100 \mathrm{~kg} \mathrm{ha}^{-1}\right)$, potassium $\left(0,80\right.$ and $\left.100 \mathrm{~kg} \mathrm{ha}^{-1}\right)$ fertilizers and various rates of organic manures (20 ton ha $\mathrm{a}^{-1}$ of farm yard manure, $20 \mathrm{tha}^{-1}$ of poultry manure and $15 \mathrm{tha}^{-1}$ of vermicompost) were applied to the soil at different combinations. The results of this study have shown that both inorganic fertilizers and organic manures significantly influenced all growth and yield parameters. Whereas, maximum plant height $(50.50 \mathrm{~cm})$ and bulb yield $\left(30.75 \mathrm{t} \mathrm{ha}^{-1}\right)$ were obtained at combination of $20 \mathrm{tha}^{-1}$ farm yard manure $+150 \mathrm{~kg} \mathrm{ha}^{-1} \mathrm{~N}+100 \mathrm{~kg} \mathrm{ha}^{-1} \mathrm{P}_{2} \mathrm{O}_{5}+100 \mathrm{~kg}$ $\mathrm{ha}^{-1} \mathrm{~K}_{2} \mathrm{O}$. However, the minimum bulb yield $\left(15.80 \mathrm{t} \mathrm{ha}^{-1}\right)$ was observed with control where no fertilizer was applied. Therefore, application of $20 \mathrm{t} \mathrm{ha}^{-1}$ farm yard manure during field preparation followed by application of $150 \mathrm{~kg} \mathrm{ha}^{-1} \mathrm{~N}$ $+100 \mathrm{~kg} \mathrm{ha}^{-1} \mathrm{P}_{2} \mathrm{O}_{5}+100 \mathrm{~kg} \mathrm{ha}^{-1} \mathrm{~K}_{2} \mathrm{O}$ can be recommended for optimal growth and maximum bulb yield of onion.
\end{abstract}

KEYWORDS: Bulb diameter, Manure, NPK, Onion, Yield

\section{INTRODUCTION}

Onion (Allium cepa L.) is one of the most important vegetables in the world. It is extensively used in many culinary preparations; therefore it commands a large internal market. Onion bulb is a rich source of carbohydrates, protein, vitamin $\mathrm{C}$, phosphorus (P) and calcium, also possess good medicinal properties (Ramesh et al., 2017). It is commonly used as flavouring or as vegetable in stews and salads. It is one of the richest sources of flavonoids in the human diet which has been associated with a reduced risk of cancer, heart disease and diabetes. Globally, the area under onion production is increasing due to its high profitability per unit area and ease of production (FAO, 2011). The mature bulb contains some starch and appreciable quantities of sugar, protein and vitamins A, B and C. National Onion Association reported that the nutrients composition of onions was given as; moisture (89\%), sugar, $(4 \%)$, protein $(1 \%)$, fiber (2\%) and $1 \%$ fat (Adeyeye et al., 2017).

Plant nutrients including chemical Fertilizers and organic manure are essential for plant growth and productivity. Fertilizers provide necessary plant nutrients, however, use of synthetic chemical fertilizers are no more considered as ecologically suitable. The alternative nutrient sources e.g., organic fertilizers have been applied to reduce the load of chemical fertilizers. In recent years, organic manures and biofertilizers used as an important component of nutrient supply system and to improve crop yield (Shah et al., 2019). Proper fertility is important in onion production as it requires well drained, non-crusting soils, with substantial amount of nutrients particularly from organic manure which improves soil physical and chemical properties (Snyman et al., 1998). Although, inorganic fertilizers provide nutrient in concentrated form for crop use, the problem of affordability and availability of inorganic fertilizer by resource-poor farmers make the use of organic manure a viable alternative (Salami \& Omotoso, 2018).

Organic material such as farmyard manure (FYM) improves soil physical and chemical properties that are important for plant growth (Snyman et al., 1998). Organic fertilizers has positive effect on root growth by improving the root rhizosphere conditions (structure, humidity, etc) and also plant growth is encouraged by increasing the population of microorganisms (Shaheen et al., 2007). It is obvious that continuous use of inorganic fertilizers and inappropriate soil fertility management practices are among the major factors limiting productivity of onion. Application of inorganic fertilizers without supplementation with organic manure has often

Copyright: $\odot$ The authors. This article is open access and licensed under the terms of the Creative Commons Attribution License (http://creativecommons.org/licenses/by/4.0/) which permits unrestricted, use, distribution and reproduction in any medium, or format for any purpose, even commercially provided the work is properly cited. Attribution - You must give appropriate credit, provide a link to the license, and indicate if changes were made. 
resulted in micronutrient deficiencies, imbalance soil physical and chemical properties and unsustainable crop production (Yohannes et al., 2017). Decomposition of organic materials would provide additional nutrients to the growing medium, which may lead to higher uptake of nutrients by the crop and subsequently high yield (Shaheen et al., 2007). In recent years the usage of chemical fertilizers indiscriminately in an unbalanced manner has been shown to result in several problems like loss of fertility, soil health and multiple nutrient deficiencies and loss of microbial activities etc, which ultimately resulting in reduced crop productivity and quality (Singh et al., 2017).

The production and nutritional values of onion are limited due to low soil fertility among many other factors, the reduction in yields of onion like other food crops has prompted farmers to amend the soils with different organic materials in order to supply the nutrients needed to enhance growth and yield of crops (Adepetu, 1997). Crops grown with organic manures are not only free from harmful chemicals, they have superior nutritional quality and free from pollutants that arise from the use of inorganic fertilizer (Yai \& Yadav, 2004).

The amount of nutrients and the type of elements available from the specific organic fertilizer used is again dependent on the age, origin as well as climatic conditions such as temperature and rainfall. It is essential to adopt a strategy of integrated nutrient management using combination of chemical fertilizers and organic manures and so as to minimize the cost of production and to maintain biological productivity of soils, particularly because the farmers are reluctant to adopt recommended fertilizer doses due to the high cost and risk of crop failure on account of aberrant weather conditions. Further, knowing the deleterious effects of using only chemical fertilizers on soil health, use of chemical fertilizers supplemented with organic waste will be environmentally benign. Therefore, this research was conducted to determine the effects of different levels of organic manures and NPK rates on growth and productivity of onion.

\section{MATERIALS AND METHODS}

This research was conducted to study the effects of organic manures and inorganic fertilizers on growth and yield of onion and find out the best combination of organic manures and inorganic fertilizers to enhance the growth and yield of onion. The mechanical and chemical analysis of soil of the experimental plot was carried out before the commencement of the experiment to ascertain the initial fertility status of the soil. Result of soil analysis is presented in Table 1.

The experiment was conducted in a completely randomized block design consisting 10 treatments with 3 three replications. Three levels of $\mathrm{N}\left(0,100\right.$ and $\left.150 \mathrm{~kg} \mathrm{ha}^{-1}\right), \mathrm{K}\left(0,80\right.$ and $100 \mathrm{~kg} \mathrm{ha}^{-}$ $\left.{ }^{1}\right)$ and $\mathrm{P}\left(0,75\right.$ and $\left.100 \mathrm{~kg} \mathrm{ha}^{-1}\right)$ fertilizers and various rates of organic manures (20 ton ha- ${ }^{-1}$ of farm yard manure, $20 \mathrm{t} \mathrm{ha}^{-1}$ of poultry manure and $15 \mathrm{t} \mathrm{ha}^{-1}$ of vermicompost) were applied to the soil at different combinations. There was a control which no fertilizer was applied. The treatment detail is given in Table 2 .
Table 1: Physical and chemical properties of field soil before sowing

\begin{tabular}{lc}
\hline Soil Properties & Quantity \\
\hline a. physical properties & \\
Sand & $30 \%$ \\
Silt & $25 \%$ \\
Clay & $44 \%$ \\
Textural Class & Sandy Loam \\
b. chemical composition of soil & \\
Organic matter & $0.851 \%$ \\
Organic carbon & $0.490 \%$ \\
Available nitrogen (Nitrate) & $0.039 \%$ \\
Available phosphorus & $0.629 \%$ \\
Available potassium & $0.064 \%$ \\
Soil pH & 7.70 \\
\hline
\end{tabular}

Table 2: Treatment details with their combinations

\begin{tabular}{|c|c|}
\hline \multicolumn{2}{|c|}{ Treatment Treatment combination } \\
\hline$T_{1}$ & No fertilizer (control) \\
\hline $\mathrm{T}_{2}^{1}$ & Farm yard manure (FYM) 20 tonne ha-1. \\
\hline $\mathrm{T}_{3}^{2}$ & Poultry manure 20 tonne ha $^{-1}$ \\
\hline $\mathrm{T}_{4}$ & Vermi compost 15 tonne ha ${ }^{-1}$ \\
\hline $\mathrm{T}_{5}^{4}$ & FYM 20 tonne ha ${ }^{-1}+\operatorname{NPK}\left(100,75,80 \mathrm{~kg} \mathrm{ha}^{-1}\right)$ \\
\hline $\mathrm{T}_{6}^{5}$ & FYM 20 tonne ha ${ }^{-1}+$ NPK 150, 100, $100 \mathrm{~kg} \mathrm{ha}^{-1}$ ) \\
\hline $\mathrm{T}_{7}$ & Poultry manure 20 tonne ha ${ }^{-1}+$ NPK $\left(100,75,80 \mathrm{~kg} \mathrm{ha}^{-1}\right)$ \\
\hline $\mathrm{T}_{8}$ & Poultry manure 20 tonne ha ${ }^{-1}+\operatorname{NPK}\left(150,100,100 \mathrm{~kg} \mathrm{ha}^{-1}\right)$ \\
\hline $\mathrm{T}_{9}^{\circ}$ & Vermicompost 15 tonne ha ${ }^{-1}+\operatorname{NPK}\left(100,75,80 \mathrm{~kg} \mathrm{ha}^{-1}\right)$ \\
\hline $\mathrm{T}_{10}$ & Vermicompost 15 tonne ha ${ }^{-1}+\operatorname{NPK}\left(150,100,100 \mathrm{~kg} \mathrm{ha}^{-1}\right)$ \\
\hline
\end{tabular}

Pusa Red which is a high yielding variety of onion was selected for the experiment. This variety is less pungent then common onion and can be stored for a long time. Seed of onion were sown separately in the nursery and 52 Days old seedlings were transplanted to the main field. The first observation was taken at $18^{\text {th }}$ days after transplanting (DAT). Subsequent observations were recorded after every 18 days interval.

Fertilizers were applied according to recommended doses for onion. $20 \mathrm{t} \mathrm{ha}^{-1}$ FYM, $20 \mathrm{tha} \mathrm{a}^{-1}$ poultry manure and $15 \mathrm{t} \mathrm{ha}^{-1}$ vermicompost were applied alone or with NPK fertilizers@ 100: 75: $80 \mathrm{~kg} \mathrm{ha}^{-1}$. Full dose of organic manures with $\mathrm{P}_{2} \mathrm{O}_{5}, \mathrm{~K}_{2} \mathrm{O}$ and half dose of nitrogen $(\mathrm{N})$ fertilizers were applied at the first time of ploughing and half dose of $\mathrm{N}$ was applied in 2 splits ( 30 and 45 days after planting). Fifty two days old seedlings were transplanted in the evening, with row to row spacing of $20 \mathrm{~cm}$ and plant to plant spacing of $10 \mathrm{~cm}$. Gap filling was done 7 days after transplanting in order to maintain uniform stand of the crop in each plot, and dead seedlings were replaced with new ones of the same age. This gap filling was continued till 15 days after transplanting.

Organic manure (FYM, Poultry and vermicompost) was well incorporated in the soil of experimental field before transplanting the seedlings in advance. Manure and fertilizers were applied according to recommended doses for onion. $\mathrm{N}$ was applied in three equal splits. Half dose of $\mathrm{N}$, total dose of $\mathrm{P}$ and potash $(\mathrm{K})$ were applied as basal dressing before transplanting. The remaining quantity of $\mathrm{N}$ was applied in two equal splits at 30 and 45 DAT. Entire quantity of vermicompost, poultry manure and FYM were also applied as basal dressing, in different 
plots as per treatment details, at the time of transplanting the seedlings. Irrigation and all other agronomic practices were carried out uniformly to all experimental plots. Onion bulbs were manually harvested. The technique of representative sample was adopted for recording the observations on various morphological characters. At every observation, five plants from each plots were randomly selected and tagged and the observations were recorded.

\section{Growth Parameters}

Growth parameters were recorded at an interval of 18 days till the complete vegetative maturity. The height of five randomly selected plants from each plot was measured in $\mathrm{cm}$ with the help of measuring tape from ground level to tip of the leaves in natural condition at 18, 36, 54, 72 and 90 days after transplanting. To measure the fresh weight of bulb $(\mathrm{g})$ the whole plant was uprooted, weighted, averaged and analysed. Bulbs were weighted, averaged and bulb weight per plant (g) was determined.

\section{Yield Parameters}

When the crop reached edible maturity, harvesting of matured bulbs was carried out. Bulb yield was calculated in $\mathrm{tha}^{-1}$ on the basis of yield per plot, averaged and subjected of statistical analysis.

\section{Statistical Analysis}

The data recorded during the course of investigation was subjected to statistical analysis by analysis of variance (ANOVA) using SPSS statistical software version 22. Treatment means were separated using Fisher's Least Significant Difference (LSD) test at 5\% probability level.

\section{RESULTS AND DISCUSSION}

\section{Plant Height $(\mathrm{cm})$}

Plant height of onion under different treatments recorded at $18,36,54,72$, and 90 days after transplanting (DAT) is shown in Table 3 . The result indicated that the effect of different treatments on plant height was insignificant at 18 DAT. However, at 36, 54, 72, and 90 DAT significant effect of different treatments was also observed. At 36 DAT, maximum plant height $(40.25 \mathrm{~cm})$ was recorded with treatment $\mathrm{T}_{5}$ and the minimum plant height $(22.17 \mathrm{~cm})$ was with $\mathrm{T}_{1}$ or control. Similar trend was observed in the successive stages of growth. At 54 DAT maximum plant height $(44.50 \mathrm{~cm})$ was recorded with treatment $\mathrm{T}_{6}$ followed by $\mathrm{T}_{5}$ and the minimum $(23.83 \mathrm{~cm})$ was with $\mathrm{T}_{1}$. At 72 DAT, maximum plant height $(47.83 \mathrm{~cm})$ was recorded with $\mathrm{T}_{6}$ treatment followed by $\mathrm{T}_{5}$. Treatment $\mathrm{T}_{3}$ and $\mathrm{T}_{9}$ were statistically at par. At 90 DAT, maximum plant height $(50.50 \mathrm{~cm})$ was produced by treatment $\mathrm{T}_{6}$, followed by $\left.\mathrm{T}_{5} 47.42 \mathrm{~cm}\right)$. Whereas, the minimum plant height $(27.17 \mathrm{~cm})$ remained with control. Treatment $\mathrm{T}_{2}, \mathrm{~T}_{7}, \mathrm{~T}_{8}$ and $\mathrm{T}_{10}$ were statistically at par.
Table 3: Effect of organic and inorganic fertilizers on plant height $(\mathrm{cm})$ of onion at different intervals

\begin{tabular}{|c|c|c|c|c|c|}
\hline \multirow[t]{2}{*}{ Treatments } & \multicolumn{5}{|c|}{ Plant height $(\mathrm{cm})$} \\
\hline & $\begin{array}{l}18 \\
\text { DAT }\end{array}$ & $\begin{array}{l}36 \\
\text { DAT }\end{array}$ & $\begin{array}{c}54 \\
\text { DAT }\end{array}$ & $\begin{array}{l}72 \\
\text { DAT }\end{array}$ & $\begin{array}{c}90 \\
\text { DAT } \\
\end{array}$ \\
\hline $\mathrm{T}_{1}$ No fertilizer (control) & 21.08 & 22.17 & 23.83 & 25.17 & 27.17 \\
\hline $\mathrm{T}_{2}$ Farm yard manure (FYM) $20 \mathrm{t} \mathrm{ha}^{-1}$. & 23.00 & 32.42 & 33.50 & 37.17 & 39.92 \\
\hline $\mathrm{T}_{3}$ Poultry manure $20 \mathrm{t} \mathrm{ha}^{-1}$ & 26.08 & 35.58 & 39.92 & 40.58 & 43.50 \\
\hline $\mathrm{T}_{4}$ Vermicompost 15 tonne ha ${ }^{-1}$ & 26.33 & 33.92 & 37.08 & 38.08 & 41.25 \\
\hline $\begin{array}{l}\mathrm{T}_{5} \mathrm{FYM} 20 \mathrm{tha}^{-1}+\operatorname{NPK}(100,75, \\
\left.80 \mathrm{~kg} \mathrm{ha}^{-1}\right)\end{array}$ & 30.42 & 40.25 & 41.78 & 45.83 & 47.42 \\
\hline $\begin{array}{l}\mathrm{T}_{6} \text { FYM } 20 \mathrm{t} \mathrm{ha}^{-1}+\text { NPK 150, 100, } \\
\left.100 \mathrm{~kg} \mathrm{ha}^{-1}\right)\end{array}$ & 28.25 & 38.18 & 44.50 & 47.83 & 50.50 \\
\hline $\begin{array}{l}\mathrm{T}_{7} \text { Poultry manure } 20 \mathrm{t} \mathrm{ha}^{-1}+\mathrm{NPK} \\
\left(100,75,80 \mathrm{~kg} \mathrm{ha}^{-1}\right)\end{array}$ & 25.33 & 30.25 & 34.25 & 35.62 & 38.59 \\
\hline $\begin{array}{l}\mathrm{T}_{8} \text { Poultry manure } 20 \mathrm{t} \mathrm{ha}^{-1}+\mathrm{NPK} \\
\left(150,100,100 \mathrm{~kg} \mathrm{ha}^{-1}\right)\end{array}$ & 25.50 & 29.75 & 34.75 & 35.17 & 39.83 \\
\hline $\begin{array}{l}\mathrm{T}_{9} \text { Vermicompost } 15 \mathrm{t} \mathrm{ha}^{-1}+\text { NPK } \\
\left(100,75,80 \mathrm{~kg} \mathrm{ha}^{-1}\right)\end{array}$ & 30.00 & 36.92 & 38.33 & 40.67 & 43.00 \\
\hline $\begin{array}{l}\mathrm{T}_{10} \text { Vermicompost } 15 \mathrm{t} \mathrm{ha}^{-1}+\mathrm{NPK} \\
\left(150,100,100 \mathrm{~kg} \mathrm{ha}^{-1}\right)\end{array}$ & 29.08 & 34.00 & 35.75 & 40.67 & 41.67 \\
\hline F-test & S & S & S & S & S \\
\hline SEm ( $( \pm)$ & 2.14 & 3.18 & 3.22 & 3.41 & 3.68 \\
\hline $\operatorname{LSD}(p=0.05)$ & 4.54 & 6.75 & 6.84 & 7.22 & 7.81 \\
\hline
\end{tabular}

It was observed that the plant height increased at all successive stages of growth. Maximum plant height was produced by treatment $\mathrm{T}_{6}$ followed by $\mathrm{T}_{5}$. Whereas, the minimum remained with $\mathrm{T}_{1}$ (control), at all the growth stages. Treatment $\mathrm{T}_{6}$ was superior to all other treatments. The increment in plant height in response to increased application of the fertilizers is attributable to the role of different nutrients in the plant in terms of enhancing photosynthetic rate and cell division, elongation and vegetative growth (Gererufael et al., 2020). Our result is in line with the findings of (Abdulrazzag, 2002) who reported similar results in onion.

\section{Fresh Weight and Bulb Diameter}

Statistical analysis of data showed that fresh weight and bulb diameter of onion were significantly affected by combined application of FYM and NPK fertilizers (Table 4). Bulb fresh weight was significantly influenced by different fertilizer treatments. Maximum bulb fresh weight $(93.74 \mathrm{~g})$ was recorded with treatment $\mathrm{T}_{6}$ followed by $\mathrm{T}_{5} 87.40 \mathrm{~g}$ ), however, $\mathrm{T}_{1}$ (control) recorded the minimum bulb fresh weight $(26.06 \mathrm{~g}) . \mathrm{T}_{3}, \mathrm{~T}_{8}, \mathrm{~T}_{7}$, and $\mathrm{T}_{9}$ were statistically at par. The highest bulb fresh weight was obtained from $\mathrm{T}_{6}$. These nutrients play an important role in improving productivity of onion bulbs. Our findings are in conformity with the results reported by (Abbey et al., 2000).

The polar diameter of bulb was significantly influenced by different treatments. $\mathrm{T}_{6}$ recorded maximum bulb polar diameter $(6.81 \mathrm{~cm})$ followed by $\mathrm{T}_{5}(6.08 \mathrm{~cm})$, while the minimum polar diameter $(3.42 \mathrm{~cm})$ was observed with $\mathrm{T}_{1}$ (control). An increasing trend in polar diameter was observed with the increase in the levels of NPK and the maximum polar diameter was recorded with the combination of Farm yard manure 20 t ha $^{-1}+\mathrm{N} 150 \mathrm{~kg} \mathrm{ha}^{-1}+\mathrm{P}_{2} \mathrm{O}_{5} 100 \mathrm{~kg} \mathrm{ha}^{-1}+\mathrm{K}_{2} \mathrm{O} 100 \mathrm{~kg} \mathrm{ha}^{-1}$ $\left(\mathrm{T}_{6}\right)$. This was probably due to better vegetative growth of plants 
Table 4: Effect of organic and inorganic fertilizers on Fresh weight and bulb diameter of onion at harvest maturity

\begin{tabular}{|c|c|c|c|}
\hline Treatments & $\begin{array}{c}\text { Fresh } \\
\text { weight of } \\
\text { bulb (g) }\end{array}$ & $\begin{array}{l}\text { Size of bulb } \\
\text { in polar } \\
\text { diameter }\end{array}$ & $\begin{array}{l}\text { Size of bulb } \\
\text { in equatorial } \\
\text { diameter }(\mathrm{cm})\end{array}$ \\
\hline$T_{1}$ No fertilizer (control) & 26.06 & 3.42 & 2.94 \\
\hline $\begin{array}{ll}\mathrm{T}_{2} & \text { Farm yard manure (FYM) } \\
20 \mathrm{t} \mathrm{ha}^{-1} .\end{array}$ & 57.74 & 4.47 & 4.03 \\
\hline $\mathrm{T}_{3}$ Poultry manure $20 \mathrm{t} \mathrm{ha}^{-1}$ & 69.41 & 4.67 & 4.41 \\
\hline $\mathrm{T}_{4}$ Vermicompost 15 tonne ha $^{-1}$ & 62.39 & 4.60 & 4.43 \\
\hline $\begin{array}{l}\mathrm{T}_{5} \mathrm{FYM} 20 \mathrm{tha}^{-1}+\mathrm{NPK}(100, \\
\left.75,80 \mathrm{~kg} \mathrm{ha}^{-1}\right)\end{array}$ & 87.40 & 6.08 & 5.13 \\
\hline $\begin{array}{l}\mathrm{T}_{6} \text { FYM } 20 \mathrm{t} \mathrm{ha}^{-1}+\text { NPK 150, } \\
\left.100,100 \mathrm{~kg} \mathrm{ha}^{-1}\right)\end{array}$ & 93.74 & 6.81 & 5.15 \\
\hline $\begin{array}{l}\mathrm{T}_{7} \text { Poultry manure } 20 \mathrm{t} \mathrm{ha}^{-1}+ \\
\operatorname{NPK}\left(100,75,80 \mathrm{~kg} \mathrm{ha}^{-1}\right)\end{array}$ & 66.07 & 4.62 & 4.53 \\
\hline $\begin{aligned} \mathrm{T}_{8} & \text { Poultry manure } 20 \mathrm{t} \mathrm{ha}^{-1}+ \\
& \operatorname{NPK}\left(150,100,100 \mathrm{~kg} \mathrm{ha}^{-1}\right)\end{aligned}$ & 69.41 & 4.62 & 4.52 \\
\hline $\begin{array}{ll}\mathrm{T}_{9} & \text { Vermicompost } 15 \mathrm{tha}^{-1}+\mathrm{NPK} \\
& \left(100,75,80 \mathrm{~kg} \mathrm{ha}^{-1}\right)\end{array}$ & 65.74 & 4.93 & 4.76 \\
\hline $\begin{array}{ll}\mathrm{T}_{10} & \text { Vermicompost } 15 \mathrm{t} \mathrm{ha}^{-1}+\text { NPK } \\
\left(150,100,100 \mathrm{~kg} \mathrm{ha}^{-1}\right)\end{array}$ & 76.42 & 5.20 & 4.88 \\
\hline F-test & $\mathrm{s}$ & $\mathrm{s}$ & $\mathrm{s}$ \\
\hline SEm ( $( \pm)$ & 3.788 & 0.547 & 0.210 \\
\hline $\operatorname{LSD}(p=0.05)$ & 8.032 & 1.160 & 0.445 \\
\hline
\end{tabular}

with availability of sufficient $\mathrm{N}, \mathrm{P}$ and potash at a higher levels. These results are supported by the findings reported by Dhaker et al. (2017) who studied the effect of different organic manures on growth and yield of onion.

Different plant nutrient treatments significantly influenced the equatorial diameter of bulb. Maximum bulb equatorial diameter $(5.15 \mathrm{~cm})$ was recorded with treatment $\mathrm{T}_{6}$ followed by $\left.\mathrm{T}_{5} 5.13 \mathrm{~cm}\right)$. While, the minimum equatorial diameter of bulb $(2.94 \mathrm{~cm})$ was observed with $\mathrm{T}_{1}$ (control). The equatorial diameter increased with increase in levels of NPK, FYM, poultry manure and vermicompost. This result is in line with the findings of Abbey et al. (2000) who indicated that combined application of FYM and inorganic fertilizer increased bulb diameter of onion.

\section{Bulb Yield ha-1}

Bulb yield of onion as influenced by application of organic and inorganic fertilizers is presented in Table 5. The data reveals that different organic and inorganic fertilizers applied in combination, significantly increased the bulb yield. The maximum bulb yield $\left(30.75 \mathrm{t} \mathrm{ha}^{-1}\right)$ was obtained from $\mathrm{T}_{6}$ followed by $\left.\mathrm{T}_{5} 28.22 \mathrm{t} \mathrm{ha}^{-1}\right)$. While, the minimum bulb yield $\left(15.80 \mathrm{t} \mathrm{ha}^{-1}\right)$ was recorded with $\mathrm{T}_{1}$ (control). Enhancing yield attributes viz., fresh weight of whole plant and bulb diameter (size) which were obtained using combined application of FYM and NPK fertilizers in this study, contributed to a higher yield of onion. Moreover, the beneficial effect of organic manures on yield might be due to additional supply of plant nutrients and improved chemical, physical and biological properties of soil (Datt et al., 2003). Our result was in close conformity with the findings of (Abbey et al., 2000; Bhati et al., 2018; Gererufael et al., 2020) who reported that higher levels of inorganic and organic fertilizers resulted in a higher bulb yield of onion.
Table 5: Effect of organic and inorganic fertilizers on bulb yield of onion $\left(\mathrm{t} \mathrm{ha}^{-1}\right)$ at harvest maturity

\begin{tabular}{|c|c|}
\hline Treatments & Bulb yield $\left(\mathrm{t} \mathrm{ha}^{-1}\right)$ \\
\hline $\mathrm{T}_{1}$ No fertilizer (control) & 15.80 \\
\hline $\mathrm{T}_{2}$ Farm yard manure (FYM) $20 \mathrm{t} \mathrm{ha}^{-1}$. & 20.49 \\
\hline $\mathrm{T}_{3}$ Poultry manure $20 \mathrm{t} \mathrm{ha}^{-1}$ & 20.40 \\
\hline $\mathrm{T}_{4}$ Vermicompost 15 tonne ha-1 & 23.10 \\
\hline $\mathrm{T}_{5}$ FYM $20 \mathrm{tha}^{-1}+\operatorname{NPK}\left(100,75,80 \mathrm{~kg} \mathrm{ha}^{-1}\right)$ & 28.22 \\
\hline $\mathrm{T}_{6}^{5}$ FYM $20 \mathrm{tha}^{-1}+$ NPK 150, 100, $100 \mathrm{~kg} \mathrm{ha}^{-1}$ ) & 30.75 \\
\hline $\begin{array}{l}\mathrm{T}_{7} \text { Poultry manure } 20 \mathrm{tha}^{-1}+\mathrm{NPK}(100,75, \\
\left.80 \mathrm{~kg} \mathrm{ha}^{-1}\right)\end{array}$ & 22.44 \\
\hline $\begin{array}{l}\mathrm{T}_{8} \text { Poultry manure } 20 \mathrm{t} \mathrm{ha}^{-1}+\text { NPK }(150,100, \\
\left.100 \mathrm{~kg} \mathrm{ha}^{-1}\right)\end{array}$ & 23.77 \\
\hline $\begin{array}{l}T_{9} \text { Vermicompost } 15 \text { t ha }^{-1}+\text { NPK }(100,75, \\
\left.80 \mathrm{~kg} \mathrm{ha}^{-1}\right)\end{array}$ & 26.18 \\
\hline $\begin{array}{l}\mathrm{T}_{10} \text { Vermicompost } 15 \mathrm{t} \mathrm{ha}^{-1}+\operatorname{NPK}(150,100, \\
\left.100 \mathrm{~kg} \mathrm{ha}^{-1}\right)\end{array}$ & 25.55 \\
\hline F-test & $\mathrm{S}$ \\
\hline $\operatorname{SEm}( \pm)$ & 1.102 \\
\hline $\operatorname{LSD}(p=0.05)$ & 2.337 \\
\hline
\end{tabular}

\section{CONCLUSION}

This study demonstrated the importance and potentials of combined application of farm yard manure in enhancing the growth and development of onion compared with the untreated (control) plots. Combined application of $20 \mathrm{t} \mathrm{ha}^{-1} \mathrm{FYM}+$ $150 \mathrm{~kg} \mathrm{ha}^{-1} \mathrm{~N}+100 \mathrm{~kg} \mathrm{ha}^{-1} \mathrm{P}_{2} \mathrm{O}_{5}+100 \mathrm{~kg} \mathrm{ha}^{-1} \mathrm{~K}_{2} \mathrm{O}$ produced the highest bulb yield of onion $\left(30.75 \mathrm{tha}^{-1}\right)$. However, bulb yield was lowest at the control treatment. Therefore, $\mathrm{T}_{6}$ treatment was found most suitable for enhancing growth and productivity of onion.

\section{AUTHORS' CONTRIBUTIONS}

This work was carried out in collaboration of both authors. Abdul Bari Andishmand designed the experiment, performed data collection and prepared the first draft. Mohammad Safar Noori assisted in designing the study, performed statistical analysis of data, revised the first draft minutely and elaborated the final manuscript for publication.

\section{REFERENCES}

Abbey, L., Joyce, D. C., Aked, J., \& Smith, B. (2000). Genotype, sulphur nutrition and soil type effect on growth and dry matter production of spring onion. Journal of Horticultura/ Science and Biotechnology, 77(3), 340-345. https://doi.org/10.1080/14620316.2002.11511503

Abdulrazzag, A. (2002). Effect of chicken manure, sheep manure and Inorganic fertilizer on yield and nutrients uptake by onion. Pakistan Journal of Biological Sciences, 5(3), 266-268. https://doi.org/10.3923/ pjbs.2002.266.268

Adepetu, J. A. (1997). Soil and Nigeria food security. Inaugural Lecture series 119. Obafemi Awolowo University, Ile-Ife. Nigeria.

Adeyeye, A. S., Ishaku, M. A, Gadu, H. O., Olalekan, K. K., \& Lamid, W. A, (2017) Comparative effect of organic and inorganic fertilizer treatments on the growth and yield of onion (Allium cepa). Research \& Reviews: Journal of Botanical Sciences, 2(2), 8-11.

Bhati, V., Yadav, P. K., \& Kumar, R. (2018). Effect of levels of inorganic fertilizers, organic manure and bio-fertilizers on plant growth attributes of onion (Allium cepa L.) cv. N-53 under hot arid region of western Rajasthan, India. International Journal of Current Microbiology and Applied Sciences, 7(2), 3593-3601. https://doi. org/10.20546/ijcmas.2018.703.413

Datt, N., Sharma, R. P., \& Sharma, G. D. (2003). Effect of supplementary use 
of farmyard manure along with chemical fertilizers on productivity and nutrient up-take by vegetable pea (Pisum sativum var arvense) and buildup of soil fertility in Lahaul valley of Himachal Pradesh. Indian Journal of Agricultural Sciences, 73(5), 266-268.

Dhaker, B., Sharma, R. K., Chhipa B. G., \& Rathore, R. S. (2017). Effect of different organic manures on yield and quality of onion (Allium cepa L.). International Journal of Current Microbiology and Applied Sciences, 6(11), 3412-3417. https://doi.org/10.20546/ ijcmas.2017.611.400

FAO. (2011) Food and Agricultural Organization of the United Nations, Rome, Italy. Retrieved from https://faostat.fao.org/site/567/defau It.aspx

Gererufael, L. A., Abraham, N. T., \& Reda, T. B. (2020). Growth and yield of onion (Allium cepa L.) as affected by farmyard manure and nitrogen fertilizer application in Tahtay Koraro District, Northwestern Zone of Tigray, Ethiopia. Vegetos, 33, 617-627. https://doi.org/10.1007/ s42535-020-00132-7

Ramesh, G., Ajithkumar, K. Amaresh Y. S., \& Savitha A. S. (2017). Influence of integrated nutrient management on growth parameters, yield and severity of disease in onion (Allium cepa L.). International Journal of Current Microbiology and Applied Sciences, 6 (8), 1020-1028. https:// doi.org/10.20546/ijcmas.2017.602.126

Salami, A. E., \& Omotoso, S. O. (2018). Performance of onion (Allium Cepa L.) enhanced by organic fertilizer in a forest agroecology,
Nigeria. Journal of Biology, Agriculture and Healthcare, 8(10), 42-48.

Shah, K. N., Chaudhary, I. J., Ranam, D. K., \& Singh, V. (2019). Impact assessment of different organic manures on growth, morphology and yield of onion (Allium cepa L.) cultivar. Asian Journal of Agricultural Research, 13(1), 20-27. https://doi.org/10.3923/ ajar.2019.20.27

Shaheen, A., Fatma, M., Rizk, A., \& Singer, S. M. (2007). Growing onion plants without chemical fertilization. Research Journal of Agriculture and Biological Sciences, 3(2), 95-104.

Singh, V., Sharma, K. C., \& Sharma, H. R. (2017) Effect of Bio-inoculants and graded level of fertilizers on nutrient uptake in garlic. International Journal of Current Microbiology and Applied Sciences, 6(5), $1200-$ 1209.

Snyman, H. G., de Joug, J., \& Aveling, T. A. S. (1998). The stabilization of sewage sludge applied to agricultural land and the effects on seedling. Water Science \& Technology, 38(2), 87-95. https://doi. org/10.1016/S0273-1223(98)00477-6

Yai, N., \& Yadav, D. S. (2004) Advances in vegetable production. Research book Centre, Karol Bagh, New Delhi. 995.

Yohannes, G. K., Kebede, W., Arvind, C., \& Fikreyohannes, G. (2017) Effect of integrated nutrient management on growth, bulb yield and storability of onion (Allium cepa L.) under irrigation at Selekeleka, Northern Ethiopia. International Journal of Life Science, 5(2), 151-160. 